\title{
Examining the Predictive Role of Authenticity on Internet Addiction in Turkish High School Students
}

\author{
Gazanfer Anli
}

Department of Psychology, Faculty of Humanities and Social Sciences, Bursa Technical University, Turkey

Copyright $\bigcirc 2018$ by authors, all rights reserved. Authors agree that this article remains permanently open access under the terms of the Creative Commons Attribution License 4.0 International License

\begin{abstract}
The aim of this research is to examine the predictive role of authenticity in internet addiction. The research was carried out with 420 high school students (280 females and 140 males). The data were obtained by using the Internet Addiction Scale and the Authenticity Scale. Correlation and multiple regression analysis were performed in which the dependent variable was internet addiction and the independent variables were subscales of authenticity. Correlation analysis showed that internet addiction was correlated negatively with authentic living and positively with self-alienation and accepting external influence. According to the results of the multiple regression analysis, self-alienation entered the equation first, accounting for $21 \%$ of the variance in predicting internet addiction. Authentic living entered on the second step accounting for an additional $7 \%$ variance. Accepting external influence entered on the third step accounting for an additional $3 \%$ variance. The standardized beta coefficients indicated the relative influence of the variables in last model with self-alienation, authentic living, and accepting external influence, all significantly influencing internet addiction and self-alienation was the strongest predictor.
\end{abstract}

Keywords Internet Addiction, Authenticity, High School Students, Correlation, Multiple Regression Analysis

\section{Introduction}

Internet addiction has become an important issue for the whole world today. It is thought that adolescents and young adults are at high risk with a significant increase in overuse and problematic internet usage worldwide [1]. Internet addiction defined as "a psychological dependence on the internet, regardless of the type of activity once logged in" [2]. Several terms describing similar concepts have been used in the literature, such as internet addiction disorder [3], internet abuse [4], internet dependence [5]; [6], problematic Internet use [7], pathological use of internet [8]; [9]; [10]; [11]; [12], compulsive use of internet [13], excessive use of internet [14] and also cyberspace addiction, online addiction [15]; [16] all refer to the same concept.

Young [10] predicted a range of criteria for diagnosing internet addiction, based on criteria used for pathological gambling in DSM-IV. She selected eight of the 10 gambling criteria most suitable to Internet use and decided that individuals who fulfill five of eight would be considered as internet dependent. These criteria contain; (1) engaging in internet, (2) increase time spent online to ensure the satisfaction, (3) frequent unsuccessful efforts to control, interrupt or halt the internet, (4) nervousness, depression or a rapidly changing mood when the internet is restricted, (5) staying online longer than originally intended, (6) establishing a dangerous business or relationship to use the internet, (7) lying to others about how much time they spent online, (8) using the Internet as a way of escaping from problems or means of regulating $\operatorname{mood}[17] ;$ [10]; [12].

Liu and Larose [18] declared that internet use among college students is an important indicator of psychological well-being. Higher online social activities were related to lower life satisfaction offline. Internet addiction can impact social functioning and academic performance in a negative way [19]. Depression and obsessive-compulsive symptoms are positively correlated with Internet addiction among adolescents [20] and adults [10]. Adolescents addicted to internet have been found to spend more time using the internet for multiplayer online games, chat rooms, multi-user domains [21]; [9]. And also, some studies show that the internet may increase a person's level of loneliness and social isolation by taking time away from social activities [22], decrease family communication and reduce size of their local social circles [23], and reduce romantic relationships and friendship quality [24]. Researches also show that problematic internet use positively correlated 
with depression [25]; [26]; [27], anxiety [25]; [27], and hostility [26] and negatively correlated with positive identity formation [28]; [29], academic achievement [30], social skills [21], emotional regulation [31] in adolescents and young adults.

John Macquarrie [32] indicated that authenticity of life to the extent that an individual takes possession of one's self and shaped that self into his or her own image. Authenticity includes a growth process whereby human being search, notice, agree and act in harmony with their real identities and to exhibit consistent behavior with inner thoughts and emotions [33]. The concept of authenticity is based on the ancient Greek philosophy, which emphasizes the happiness and well-being of the individuals in keeping with the values, desires and beliefs of them [33]; [34]. Recently, humanist psychologists [35]; [36]; [37]; [38], existentialist psychologists [39]; [40], philosophers [41]; [42], psychodynamic writers [43]; [44] have developed extensive and complicated accounts on authenticity.

Most modern theoretical references to authenticity have been created from a humanistic perspective. This perspective generally accepts the presence of a real self, which arises through self-discovery and self-acceptance and is associated with a person's psychological well-being [45]. The concept of authenticity emphasizes the importance of behaviors that reflect the inner experiences of individuals and the freedom to express themselves [46]. Researches showed that authenticity is positively correlated with decreased psychological distress [47], raised mood [48], higher level of life-satisfaction and subjective well-being [49] and having the meaning of life [50].

Some scholars support that the development of an authentic sense of self may decrease distress feelings that are often experienced during some transitional periods [51]. It was generally stated that authenticity is related to dimensions of personal and interpersonal functioning [47]. Authenticity is negatively correlated with anxiety, stress, depression, self-alienation [52]; [53] and positively correlated with self-esteem [47], daily self-esteem [53], mindfulness [52], life satisfaction [53] and subjective and psychological well-being [49]; [53].

Despite these findings, to our knowledge, no study has investigated the relationship between authenticity and internet addiction. Thus, the aim of this study is to examine the predictive role of authenticity on internet addiction. Internet addiction is positively related to maladaptive constructs as depression [25]; [26]; [27], hostility [26] and anxiety [27]. Wood et al. [53] found that accepting external influence and self-alienation had positive correlation with stress and anxiety and had negative relation with adaptive constructs such as happiness and self-esteem. Otherwise authentic living is positively related to happiness and self-esteem, and negatively related to anxiety and stress. Based on the relationships presented above, this study poses the following hypotheses:
1) Accepting external influence is positively correlated with internet addiction.

2) Self-alienation is positively correlated with internet addiction.

3) Authentic living is negatively correlated with internet addiction.

\section{Method}

\subsection{Research Model}

It is correlational research since the relationship between two or more variables is examined without intervention of variables [54].

\subsection{Participants}

The study conducted with 420 students study at 12th class of Umraniye Center Anatolian High School, during 2016/2017 academic term. The split between genders was in favor of female with $63,3 \%$ (280) female and $31,7 \%$ (140) male. The ages ranged from 17 to 18 years old $(M=$ $17.7, S D=.41)$. In selection of participants, due to the limitations of time, money and labor, the convenience sampling method was determined which enables the sample to be selected from easily accessible and practical units [55].

\subsection{Data Collection Tools}

\subsubsection{Authenticity Scale}

This scale was developed by Wood et al. [53]. The scale is a 12-item self-report inventory. The scale is a Likert type which take values of $1,2,3 \ldots 7$ and include expressions between "it's definitely not right for me." and "it's definitely right for me." The scale is a measurement tool consisting of 12 sub-items and three sub-scales. These sub-scales are self-alienation, accepting external influence and authentic living. The highest score from this scale is 84 and the lowest score is 12 . The higher score obtained from each subscale indicates that the relevant subscale has the characteristics evaluated. As a result of factor analysis to determine the structure validity of the scale, it was observed that the scale has three sub-dimensions that are compatible with the original form. The factor loadings of the items range from .60 to .83. A Turkish adaptation of this scale by İlhan and Özdemir [56] with 240 Turkish university students (161 women, 79 men), has three factors explaining $26 \%$ of the total variance. Confirmatory factor analysis provided good fit indexes $\left(\chi^{2} / \mathrm{sd}=1.49\right.$, RMSEA $=.05, \mathrm{CFI}=.95$, IFI $=.95, \mathrm{GFI}=.92)$. Internal consistencies were .79 for self-alienation, .72 for accepting external influence, and .75 for authentic living. In the present research, the reliability coefficient acquired from the scale was .71 . 


\subsubsection{Internet Addiction Test (IAT)}

The diagnostic questionnaire, which was developed by Kimberly Young [10], adapted to the "pathological gambling" criteria of DSM - IV, was later developed and an internet addiction scale of 20 questions was created. On the Internet addiction scale, participants are asked to select one of the "never", "rarely", "occasionally", "mostly" and "continuous" options. This is a 5-point Likert type scale between 1 (never) and 5 (always). "Those who have scores between 20-39 are defined as" average internet users "who does not live any problems related to internet usage in their life. Those who have scores between 40-69 points are defined as "risky internet use" group who have some internet related problems in their daily life. Taking a score of 70-100 in the total of the survey is considered as a sign of significant deterioration in the functioning and this group is defined as "internet addict". Turkish adaptation of the scale had been done by Bayraktar [57]. The Cronbach alpha value acquired from the scale was reported by Bayraktar as .91 and Spearman-Brown value as .87. It is indicated that the model was significant in consequence of the regression analysis (f: 11.29) $=26.165 \mathrm{p}<.01$ ). In the present research, the reliability coefficient acquired from the scale was .92 .

\subsection{Procedure and Analysis of Data}

Permission for students to take part in the application is taken from school administrations and voluntary participation of students is provided, Informed Consent Form, Authenticity Scale and Internet Addiction Test were administered to 12 grade students who were volunteer to participate. All questionnaires were administered during the course hours as groups.

Pearson Product-Moment Correlation and stepwise multiple linear regression analysis used to investigate the correlations between authenticity and internet addiction. The variables entered in multiple regression analysis were measured by summing the items of each scale. Data was analyzed by using IBM SPSS 13.0 program with significance levels of .05 and .01 .

\section{Findings}

\subsection{Descriptive Data and Inter-correlations}

Table 1 indicates the means, standard deviations, alphas and intercorrelations of the variables.

As seen at Table 1, correlation analysis indicated that authentic living $(r=-.39 ; \mathrm{p}<.01)$ was correlated negatively with internet addiction. Self-alienation $(r=.46 ; \mathrm{p}<.01)$ and accepting external influence $(r=.36 ; \quad \mathrm{p}<.01)$ were positively correlated with internet addiction.
Table 1. Descriptive Statistics and Inter-Correlations of the Variables

\begin{tabular}{|c|c|c|c|c|}
\hline Variables & 1 & 2 & 3 & 4 \\
\hline 1. Authentic Living & - & & & \\
\hline $\begin{array}{c}\text { 2. Accepting External } \\
\text { Influence }\end{array}$ & $-.31^{* *}$ & - & & \\
\hline 3. Self-alienation & $-.32^{* *}$ & $.35^{* *}$ & - & \\
\hline 4. Internet Addiction & $-.39 * *$ & $.36 * *$ & $.46 * *$ & - \\
\hline Mean & 22,72 & 15,54 & 16,03 & 29,25 \\
\hline Sd & 5,46 & 5,50 & 6,47 & 17,69 \\
\hline Skewness & -.89 & .29 & .15 & -.59 \\
\hline Kurtosis & .55 & -.62 & -.65 & .60 \\
\hline Cronbach's $\alpha$ & .77 & .72 & .66 & .91 \\
\hline$* * \mathrm{p}<.01 \quad$ * $<<.05$ & & & \\
\hline
\end{tabular}

Before regression was applied, multiple regression assumptions were checked. First, the data were analyzed with Kolmogorov-Smirnov test in terms of normality. According to Kolmogorov-Smirnov test, the distribution of test scores for all tests was normal. Outlier values were investigated using the distance of Mahalanobis. When probability associated with its D2 is .001 or less, this case accepted as an outlier [58]. Depending on this measure, ten data were indicated as outliers and deleted. All the VIF values found less than 10 [58]. It was also seen that Durbin-Watson values were between 1.5 and 2.5, condition index (CI) values were less than 30 [59]. All of these values show that there was not any multi-collinearity and the conditions necessary for regression analysis were met.

Table 2. The Summary of Stepwise Regression Analysis for Variables

\begin{tabular}{|c|c|c|c|c|c|}
\hline Variables & $\mathrm{B}$ & $\mathrm{SE}$ & $\beta$ & $\mathrm{t} * *$ & $\mathrm{P}$ \\
\hline Step 1: $\mathrm{R}^{2}=.21$, adjusted $\mathrm{R}^{2}=.20, \mathrm{~F}(1,418)=111.972, \mathrm{p}<.01$. \\
\hline Self-alienation & 1.25 & .11 & .46 & 10,582 & .000 \\
\hline Step 2: $\mathrm{R}^{2}=.28, \Delta \mathrm{R}^{2}=.07$, adjusted $\mathrm{R}^{2}=.27, F(1,417)=39.207$, \\
$p<.01$ \\
\hline Self-alienation & 1.02 & .12 & .37 & 8.540 & .000 \\
\hline Authentic Living & -.88 & .14 & -.27 & -6.262 & .000 \\
\hline Step 3: $\mathrm{R}^{2}=.31, \Delta \mathrm{R}^{2}=.03$, adjusted $\mathrm{R}^{2}=.30, F(1,416)=16.754$, \\
\hline \multicolumn{5}{|c|}{$p<.01$} \\
\hline Self-alienation & .88 & .11 & .32 & 7.213 & .000 \\
\hline Authentic Living & -.75 & .14 & -.23 & -5.285 & .000 \\
\hline $\begin{array}{c}\text { Accepting External } \\
\text { Influence }\end{array}$ & .58 & .14 & .18 & 4.093 & .000 \\
\hline \multirow{2}{*}{$* * \mathrm{p}<.01 * \mathrm{p}<.05$} & & & & \\
\hline
\end{tabular}

As seen at Table 2, Multiple regression analysis was applied in which the dependent variable was internet addiction and the independent variables were subscales of authenticity. The stepwise regression method was used to determine the predictive and explanatory power of each independent variable separately on the dependent variable. Three stepwise multiple regression analyses were applied to determine which dimensions of authenticity were the best predictors of internet addiction. In the three-step regression analysis, firstly self-alienation participated the 
equation, explaining $21 \%$ of the variance in predicting internet addiction $\left(\mathrm{R}^{2}=.21\right.$, adjusted $\mathrm{R}^{2}=.20, F(1,418)=$ $111.972, p<.01)$. Authentic living participated on the second step explaining an additional $7 \%$ variance $\left(\mathrm{R}^{2}=.28\right.$, $\Delta \mathrm{R}^{2}=.07$, adjusted $\left.\mathrm{R}^{2}=.27, F(1,417)=39.207, p<.01\right)$. Accepting external influence participated on the third step explaining an additional $3 \%$ variance $\left(\mathrm{R}^{2}=.31, \Delta \mathrm{R}^{2}=.03\right.$, adjusted $\left.\mathrm{R}^{2}=.30, F(1,416)=16.754, p<.01\right)$. In the last model, when the standard beta coefficients were analyzed the independent variables self-alienation $(\beta=.32, p<.01)$, authentic living $(\beta=-.23, p<.01)$, and accepting external influence $(\beta=.18, p<.01)$ were found to be significant predictors of internet addiction and self-alienation was the strongest predictor of internet addiction.

\section{Discussion and Conclusions}

The purpose of this research is to examine the predictive role of authenticity on internet addiction. It was supposed that authentic living is correlated negatively and self-alienation and accepting external influence are correlated positively with internet addiction. Findings from correlation and regression analysis confirm these hypotheses and revealed the importance of authenticity to better understand the internet addiction.

Firstly, as hypothesized self-alienation predicted internet addiction positively. Some researches show that internet addiction is negatively correlated with positive identity formation [28]; [29], and emotional regulation [31] in adolescents and young adults. In addition, some studies have shown that the internet addiction can increase the levels of shyness and loneliness by keeping individuals from social activities [22], reduce family relations and restrict the size of individuals' local social environments [23]. These findings support our study.

Secondly, as expected, accepting external influence predicted internet addiction positively. Wood et al. [53] found that accepting external influence is correlated negatively with positive affect and positively with negative affect. People with high accepting external influence cannot make authentic choices freely from others' pressure and it effects people's health and well-being in negative way [60]. Some studies show that internet addiction leads to anxiety [61], deterioration in mental health [62]; [63] and substance use problems. As a result, it has been found that internet addiction lowers individuals' well-being [64].

Finally, findings of our research show that authentic living was found to be negatively related to internet addiction. Internet's various and intriguing applications such as multi-player games have proven to be an attractive starting point for people who are prone to escape from their problems [65]. Internet addiction can lead to undesirable consequences such as poor sleep, problems with eating meals, limited physical activity, deterioration of school and work life and other daily activities [66].
These situations may mean that individuals move away from an authentic lifestyle.

\section{Recommendations}

The results of this study are remarkable, but some limitations exist. Since participants are only in the high school group, this research can be done in different sample groups such as middle school and university to get better results. This study was carried out with the aim of finding relationships between these variables. Thus, longitudinal and experimental studies of how authenticity and its' dimensions are effective on internet addiction can also be achieved. In order to support the findings of the present study, different studies can be done using authenticity, internet addiction and various variables and instrument roles of different variables can be examined. In addition, educational programs to reduce internet addiction and enhance the level of authenticity can be planned and implemented in school environment.

\section{Declaration of Conflicting Interests}

The author(s) declared no potential conflicts of interest with respect to the research, authorship, and /or publication of this article.

\section{Funding}

The author(s) received no financial support for the research and/or authorship of this article

\section{REFERENCES}

[1] Spada, M. M. (2014). An overview of problematic Internet use. Addictive Behaviors, 39, 3-6. Doi: 10.1016/j.addbeh.2013.09.007

[2] Kandell, J. J. (1998). Internet addiction on campus: The vulnerability of college students. Cyberpsychology and Behavior, 1(1), 11-17.

http://dx.doi.org/10.1089/cpb.1998.1.11

[3] Goldberg, I. (1995). Internet addictive disorder (IAD) diagnostic criteria. Retrieved 9 January 2013, from:http://catless.ncl.ac.uk/Risks/17.12.html\#subj6.1

[4] Brenner, V. (1997). Psychology of computer use: XLVII. Parameters of Internet use, abuse and addiction: The first 90 days of the Internet usage survey. Psychological Reports, 879-882. DOI: $10.2466 /$ pr0.1997.80.3.879.

[5] Scherer, K. (1997, August). College life online: healthy and unhealthy internet use. Paper presented at the 104th annual meeting of the American Psychological Association, Chicago. 
[6] Anderson, K. J. (2001). Internet use among college students: An exploratory study. Journal of American College Health, 50, 21-26. Doi:10.1080/07448480109595707

[7] Beard, K. \& Wolf, E. (2001). Modification in the proposed diagnostic criteria for internet addiction. Cyber psychology and Behavior, 4, 377-383. Doi:10.1089/1094931013002102 86.

[8] Davis, R. A. (2001). A cognitive-behavioral model of Pathological Internet Use (PIU). Computers in Human Behavior, 17(2), 187-195.

https://doi.org/10.1016/S0747-5632(00)00041-8

[9] Morahan-Martin, J. (2005). Internet abuse - Addiction? Disorder? Symptom? Alternative explanations? Social Science Computer Review, 23(1), 39-48. https://doi.org/10.1177/0894439304271533.

[10] Young, K. S. (1996, August). Internet addiction: The emergence of a new clinical disorder. Paper presented at the 104th Annual Meeting of the American Psychological Association, Toronto, Ontario, Canada

[11] Young, K. S. (1997, August). What makes the internet addictive: Potential explanations for pathological internet use. Paper presented at the 105th annual conference of the American Psychological Association, Chicago, IL.

[12] Young, K. S. (1999). Internet addiction: Symptoms, evaluation, and treatment. In T. Jackson (Ed.), Innovations in clinical practice: A source book (Vol. 17, pp. 1931). Sarasota, FL.: Professional Resource Press.

[13] Meerkerk, G. J., Van den Eijnden, R., \& Garretsen, H. F. L. (2006). Predicting compulsive Internet use: It's all about sex! Cyber Psychology and Behavior, 9(1), 95-103. https://doi.org/10.1089/cpb.2006.9.95

[14] Suhail, K. (2006). Effects of excessive Internet use on undergraduate students in Pakistan. Cyber Psychology and Behavior, 9(3), 297-307. Doi: 10.1089/cpb.2006.9.297

[15] Hur, M. H. (2006). Demographic, habitual, and socioeconomic determinants of Internet addiction disorder: An empirical study of Korean teenagers. Cyber Psychology and Behavior, 9(5), 514-525. DOI: 10.1089/cpb.2006.9.514.

[16] Orzack, M. (1999). Computer addiction: Is it real or is it virtual? Harvard Mental Health Letter, 15(7), 8.

[17] Widyanto, L., \& Griffiths, M. (2006). 'Internet Addiction': A critical review. International Journal of Mental Health Addict, 4, 31-25. Doi:10.1007/s11469-006-9009-9

[18] Liu, X. \& Larose, R. (2008). Does Using the Internet Make People More Satisfied with their Lives? The Effects of the Internet on College Students' School Life Satisfaction. Cyber Psychology and Behavior, 11(3), 310-320. Doi: 10.1089/cpb.2007.0040

[19] Young, K. S. (2006). Surfing not studying: Dealing with internet addiction on campus. Retrieved February 25, 2009 from:

http://www.netaddiction.com/articles/surfing not_studying. htm

[20] Ha, J. H., Kim, S. Y., Bae, S. C, Bae, S., Kim, H., M. S., Sim, K., Lyoo \& S. C., Cho. (2007). Depression and
Internet Addiction in Adolescents. Psychopathology, 40(6), 424-430. Doi:10.1159/000107426

[21] Griffiths, M., \& Wood, R. T. A. (2000). Risk factors in adolescence: The case of gambling, videogame playing, and the internet. Journal of Gambling Studies, 16, 199-225. https://doi.org/10.1023/A:1009433014881

[22] Seepersad, S. (2004). Coping with loneliness: Adolescent online and offline behavior. Cyber Psychology and Behavior, 7(1), 35-39.

[23] Sanders, C. E., Field, T. M., Diego, M., Kaplan, M. (2000). The Relationship of internet use to depression and social isolation among adolescents. Adolescence, 35(138), 237-241.

[24] Blais, J. J., Craig, W. M., Pepler, D., \& Connolly, J. (2008). Adolescents online: The Importance of internet activity choices to salient relationships. Journal of Youth and Adolescence, $\quad 37(5), \quad 522-536$ http://dx.doi.org/10.1007/s10964-007-9262-7

[25] Dong, G., Lu, Q., Zhou, H., \& Zhao, X. (2011). Precursor or sequela: Pathological disorders in people with Internet addiction disorder. PLoS One, 6(2), e14703. https://doi.org/10.1371/journal.pone.0014703

[26] Gentile, D. A., Choo, H., Liau, A., Sim, T., Li, D., Fung, D., $\&$ Khoo, A. (2011). Pathological video game use among youths: A two-year longitudinal study. Pediatrics, 127(2), e319-e329. https://doi.org/10.1542/peds.2010-1353

[27] Selfhout, M. H. W., Branje, S. J. T., Delsing, M., ter Bogt, T. F. M., \& Meeus, W. H. J. (2009). Different types of Internet use, depression, and social anxiety: The role of perceived friendship quality. Journal of Adolescence, 32(4), 819-833.

doi:https://doi.org/10.1016/j.adolescence.2008.10.011

[28] Kim, Y. R., Son, J. W., Lee, S. I., Shin, C. J., Kim, S. K., Ju, G., Choi, W. H., Oh, J. H., Lee, S., Jo, S., \& Ha, T. H. (2012). Abnormal brain activation of adolescent Internet addict in a ball-throwing animation task: Possible neural correlates of disembodiment revealed by fMRI. Progress in Neuro-Psychopharmacology and Biological Psychiatry, 39(1), 88-95. doi:https://doi.org/10.1016/j.pnpbp.2012.05.013

[29] Yuan, K., Qin, W., Wang, G., Zeng, F., Zhao, L., Yang, X., Liu, P., Liu, J., Sun, J., von Deneen, K. M., Gong, Q., Liu, Y., \& Tian, J. (2011). Microstructure abnormalities in adolescents with internet addiction disorder. PLoS One, 6(6), e20708.

doi:https://doi.org/10.1371/journal.pone.0020708

[30] Stavropoulos, V., Alexandraki, K., \& Motti-Stefanidi, F. (2013). Flow and telepresence contributing to Internet abuse: Differences according to gender and age. Computers in Human Behavior, 29(5), 1941-1948. Doi: https://doi.org/10.1016/j.chb.2013.03.011

[31] Anderson, E. L., Steen, E., \& Stavropoulos, V. (2016). Internet use and problematic internet use: A systematic review of longitudinal research trends in adolescence and emergent adulthood. International Journal of Adolescence and Youth, 1, 1-25. https://doi.org/10.1080/02673843.2016.1227716. 
[32] Macquarrie, J. (1972). Existentialism. London: Philadelphia.

[33] Harter, S. (2002). Authenticity. In C. R. Snyder \& S. J. Lopez (Eds.), Handbook of positive psychology ( $\mathrm{pp}$. 382-394). New York, NY: Oxford University Press.

[34] Waterman, A. S. (1993). Two conceptions of happiness: Contrasts of personal expressiveness (eudaimonia) and hedonic enjoyment. Journal of Personality and Social Psychology, 64, 678-691. http://dx.doi.org/10.1037/0022-3514.64.4.678

[35] Maslow, A. H. (1959). Psychological data and value theory. In A.H. Maslow (Ed.), New knowledge in human values (pp.119-136). New York: Harper and Row, Inc.

[36] Rogers, C. R. (1961). On becoming a person: A therapist's view of psychotherapy. London: Constable.

[37] Rogers, C. R. (1964). Toward a modern approach to values: The valuing process in the mature person. Journal of Abnormal and Social Psychology, 68, 160-167.

[38] Rogers, C. R. (1980). A way of being. Boston: Houghton Mifflin.

[39] May, R. (1981). Freedom and destiny. New York: Basic Books.

[40] Yalom, I. D. (1980). Existential psychotherapy. New York: Basic Books.

[41] Heidegger, M. (1962). Being and time. Translated by John Macquarrie and Edward Robinson. Oxford: Basil Blackwell.

[42] Sartre, J. P. (1956). Being and nothingness. Translated by H.E. Barnes. Washington Square Press.

[43] Horney, K. (1951). Neurosis and human growth. London: Routledge.

[44] Winnicott, D. W. (1965). The maturational processes and the facilitating environment. New York: International Universities Press.

[45] Hansen, J. T. (2005). Postmodernism and humanism: A proposed integration of perspectives that value human meaning systems. Journal of Humanistic Counseling, Education and Development, 44, 3-15. Doi:10.1002/j.2164-490X.2005.tb00052.x

[46] Peterson, C., \& Seligman, M. E. (2004). Character strengths and virtues: A handbook and classification. New York: Oxford University Press.

[47] Kernis, M. H. \& Goldman, B. M. (2006). A multicomponent conceptualisation of authenticity: Theory and research. In M.P. Zanna (Ed.), Advances in experimental social psychology (Vol. 38, pp. 283-357). San Diego, CA: Elsevier Academic Press.

[48] Bettencourt, B. A., and Sheldon, K. (2001). Social roles as mechanisms for psychological need satisfaction within social groups. Journal of Personality and Social Psychology, 81, 1131-1143.

http://dx.doi.org/10.1037/0022-3514.81.6.1131

[49] Sheldon, K. M., Ryan, R. M., Rawsthorne, L. J., \& Ilardi, B. (1997). Trait self and true self: Cross-role variation in the big-five personality traits and its relations with psychological authenticity and subjective well-being. Journal of Personality and Social Psychology, 73, 1380-1393. Doi:10.1037/0022-3514.73.6.1380

[50] Schlegel, R. J., Hicks, J. A., Arndt, J., \& King, L. A. (2009). Thine own self: True self-concept accessibility and meaning in life. Journal of Personality and Social Psychology, 96, 473-490. Doi: 10.1037/a0014060

[51] Reich, W. A., Harber, K. D., \& Siegel, H. I. (2008). Self-structure and well-being in life transitions. Self and Identity, 7, 129-150. https://doi.org/10.1080/15298860601119940

[52] Kernis, M. H., \& Goldman, B. M. (2005). Authenticity, social motivation, and psychological adjustment. In Social motivation: Conscious and unconscious processes, (pp. 210-227). New York, NY US: Cambridge University Press.

[53] Wood, A. M., Linley, P. A., Maltby, J., Baliousis, M., \& Joseph, S. (2008). The authentic personality: A theoretical and empirical conceptualization and the development of the Authenticity Scale. Journal of Counseling Psychology, 55(3), 385-399.

http://dx.doi.org/10.1037/0022-0167.55.3.385

[54] Büyüköztürk, Ş., K1lıç Çakmak, E., Akgün, Ö. E., Karadeniz, Ş. \& Demirel, F. (2012). Bilimsel araştırma yöntemleri (Scientific research methods). Ankara: Pegem Akademi Publishing.

[55] Bryman, A. (2004). Social research methods (2nd edition). Oxford: Oxford University Press.

[56] İlhan, T., \& Özdemir, Y. (2013). Adaptation of authenticity scale to Turkish: A validity and reliability study. Turkish Psychological Counseling and Guidance Journal, 5(40), 142-153.

[57] Bayraktar, F. (2001). The Role of internet usage in the development of adolescents, unpublished master's thesis, Ege University, Institute of Social Sciences, Izmir.

[58] Tabachnick, B. G., \& Fidell, L. S. (2001). Using multivariate statistics. Boston: Allyn and Bacon.

[59] Büyüköztürk, Ş. (2009). Data analysis handbook for social sciences: Statistics, research design, spss server and comment. Ankara: Pegem Akademi Publishing.

[60] Deci, E. L. \& Ryan, R. M. (2004). Autonomy is no illusion: Self-determination theory and the empirical study of authenticity, awareness, and will. J. Greenberg, S. L. Koole ve T. Pyszczynski, (Ed.), Handbook of experimental existential psychology, (449-479). New York: Guilford.

[61] Lee, M. S., Oh, E. Y., Cho, S. M., Hong, M. J., \& Moon, J. S. (2001). An assessment of adolescent Internet addiction problems related to depression, social anxiety and peer relationship. Journal of Korean Neuropsychiatric Association, 40(4), 616-628.

[62] Ciarrochi, J., Parker, P., Sahdra, B., Marshall, S., Jackson, C., Gloster, A. T., et al. (2015). The development of compulsive Internet use and mental health: A four-year study of adolescence. Developmental Psychology, 52, 272283. Doi: $10.1037 / \operatorname{dev} 0000070$ 
[63] Salmela-Aro, K., Upadyaya, K., Hakkarainen, K., Lonka, K. \& Alho, K. (2017). The dark side of Internet use: Two longitudinal studies of excessive Internet use, depressive symptoms, school burnout and engagement among Finnish early and late adolescents. Journal of Youth and Adolescence, 46, 343-357. Doi:

10.1007/s10964-016-0494-2

[64] Odacı, H. \& Çıkrıkçı, Ö. (2014). Problematic Internet use in terms of gender, attachment styles and subjective well-being in university students. Computers in Human
Behavior, 32, 61-66. Doi: 10.1016/j.chb.2013.11.019.

[65] Kuss, D. J., \& Griffiths, M. D. (2012). Internet gaming addiction: A systematic review of empirical research. International Journal of Mental Health Addiction, 10(2), 278-296. https://doi.org/10.1007/s11469-011-9318-5

[66] Cao, F. \& Su, L. (2006). Internet addiction among Chinese adolescents: Prevalence and psychological features. Child: Care, Health and Development, 33(3), 275-281. Doi: 10.1111/j.1365-2214.2006.00715.x 